\title{
Hubungan Faktor Risiko dengan Kejadian Leimioma Uteri di RSUD dr. Zainoel Abidin Banda Aceh
}

\author{
Risk Factors with Genesis Leimioma uteri in RSUD dr. Zainoel Abidin \\ Banda Aceh \\ Yolla Asmaul Nufra* ${ }^{1}$, Azimar ${ }^{2}$ \\ ${ }^{1,2}$ Akademi Kebidanan Munawarah, Jalan Sultan Iskandar Muda, No. 18 Kota Juang, Bireuen \\ *Korespondensi Penulis: yollaasmaul_nufra@yahoo.com
}

\begin{abstract}
Abstrak
Mioma uteri adalah tumor jinak otot polos uterus yang terdiri dari sel-sel jaringan otot polos, jaringan pengikat fibroid dan kolagen. Mioma uteri terjadi pada 20\%-25\% perempuan diusia reproduktif, Faktor-faktor risiko seperti umur, paritas, umur menarche dan riwayat keluarga dapat menyebabkan terjadinya mioma uteri. Tujuan penelitian ini untuk menganalisis Hubungan Faktor Risiko Kejadian Leimioma Uteri Di RSUD dr. Zainoel Abidin Banda Aceh Tahun 2018. Desain yang digunakan dalam penelitian ini adalah observasi analitik dengan pendekatan case-control, dipelajari secara retrospektif. Populasi adalah ibu mengalami mioma uteri priode Maret-Juli 2018 sebanyak 152 responden dan perhitungan sampel menggunakan rumus Odd Ratio (OR) dengan jumlah sampel 76 case dan 76 kontrol, teknik pengambilan sampel konsekutive sampling. Analisis yang digunakan adalah uji statistik Chi Square. Terdapat hubungan bermakna antara umur dengan kejadian mioma uteri ( $\mathrm{p}$-value $=0,000$ $\mathrm{OR}=4.317$ ), tidak terdapat hubungan bermakna antara paritas dengan kejadian mioma uteri ( $\mathrm{p}$ value $=0,003 \mathrm{OR}=2.792)$, terdapat hubungan bermakna antara usia menarche dengan kejadian mioma uteri ( $\mathrm{p}$-value $=0,002 \mathrm{OR}=3.068$ ) dan terdapat hubungan bermakna antara riwayat keluarga dengan kejadian mioma uteri ( $\mathrm{p}$-value $=0,002 \mathrm{OR}=3.201$ ). Bagi Dinas Kesehatan Provinsi Aceh khususnya Kepala Bidang Kesehatan Masyarakat yang membawahi Seksi Promosi dan Pemberdayaan Masyarakat agar dapat melakukan berbagai upaya, guna mengatasi masalah mioma uteri dan dapat diteruskan melalui Unit Pelaksanaan Teknis Daerah (UPTD) Bapelkes.
\end{abstract}

Kata kunci: Faktor Risiko, Umur, Usia Menarche, Paritas, Riwayat keluarga

\begin{abstract}
Myoma uteri are benign tumors of the uterine smooth muscle cells consists of smooth muscle tissue, connective tissue and collagen fibroids. Myoma uteri occurs in 20\% -25\% of women of reproductive age, risk factors such as age, parity, age of menarche and family history can cause myoma uteri. This study aimed to identify risk factors (age, parity, age of menarche and family history) with the incidence of myoma uteri in Banda Aceh RSUDZA 2018. The design used in this study is analytic observation with a case-control approach, studied retrospectively. The population was mothers experiencing uterine myoma period March-July 2018 as many as 152 respondents and the sample calculation used the Odd Ratio (OR) formula with a sample number of 76 cases and 76 controls, a cooperative sampling technique.
\end{abstract}


The analysis used is Chi Square There was a significant relationship between age and incidence of myoma uteri ( $p$-value $=0.000 \mathrm{OR}=4,317$ ), there is no significant relationship between parity with the incidence of myoma uteri ( $p$-value $=0,003 \mathrm{OR}=2,792$ ), there is a significant relationship between age of menarche with incidence of myoma uteri ( $p$-value = $0,002 \mathrm{OR}=3,068$ ) and there was a significant relationship between family history and incidence of myoma uteri ( $p$-value $=0,002$ OR =3,201). For particular Aceh Provincial Health Office Head of Public Health Promotion Section charge and Empowerment in order to make efforts to address the problems myoma uteri and can be passed through the Regional Technical Implementation Unit (UPTD) Bapelkes.

Keywords: Risk Factors, Age, Age of Menarche, Parity, Family History

\section{PENDAHULUAN}

Menurut World Health Organization (WHO), kesehatan reproduksi merupakan suatu keadaan kesejahteraan fisik, mental dan sosial secara utuh bukan hanya bebas dari penyakit atau kecacatan dalam segala aspek yang berhubungan dengan sistem reproduksi, fungsi, serta prosesnya (Depkes RI, 2005).

Kesehatan reproduksi wanita memberi pengaruh yang besar dan berperan penting terhadap kelanjutan generasi penerus bagi suatu negara. kesehatan reproduksi remaja juga merupakan parameter kemampuan negara dalam menyelenggarakan pelayanan kesehatan terhadap masyarakat (Lilyani, 2012).

Masalah kesehatan reproduksi wanita salah satunya yaitu leimioma uteri dikenal juga dengan fibromioma, fibroid maupun mioma. Mioma uteri merupakan tumor pelvis yang terbanyak pada organ reproduksi wanita. Mioma uteri merupakan tumor jinak yang struktur utamanya adalah otot polos rahim. Mioma uteri terjadi pada 20\%-25\% perempuan diusia reproduktif, tetapi oleh faktor yang tidak diketahui secara pasti. Insidennya 3-9 kali lebih banyak pada ras kulit berwarna dibandingkan dengan ras kulit putih (Anwar, 2011).

Namun tidak jelas apakah perbedaan ini adalah genetik atau karena kadar peningkatan estrogen, peneliti terbaru menemukan bahwa Val/Val genotip dari enzim penting untuk metabolisme estrogen, catechol-O-methyltransferase (COMT), ditemukan pada 47\% wanita Afrika-Amerika tetapi hanya 19\% dari wanita kulit putih, wanita dengan genotip ini lebih mungkin untuk mengembangkan mioma uteri yang mungkin menjelaskan prevalensi lebih tinggi dari mioma antara perempuan Afrika-Amerika (ASRM, 2007).

Jarang sekali mioma ditemukan pada wanita berumur 20 tahun, paling banyak pada umur 35-45 tahun (kurang lebih 25\%). Pertumbuhan mioma diperkirakan memerlukan waktu 3 tahun agar dapat mencapai ukuran sebesar tinju, akan tetapi beberapa kasus ternyata tumbuh 
cepat. Umumnya mioma uteri terjadi pada beberapa tempat, ukuran rerata tumor ini adalah 15 $\mathrm{cm}$, tetapi cukup banyak yang melaporkan kasus mioma uteri dengan berat mencapai $45 \mathrm{~kg}$ (Anwar, 2011).

Pengobatan mioma uteri dengan gejala klinik di Indonesia pada umumnya adalah tindakan operasi yaitu histerektomi (pengangkatan rahim) atau pada wanita yang ingin mempertahankan kesuburannya, miomektomi (pengangkatan mioma) dapat menjadi pilihan (Manuaba, 2009). Apabila ukuran mioma uteri melebihi umur 14 minggu sebaiknya tindakan yang harus dilakukan adalah histerektomi jika kurang dari 12 minggu dapat dianjurkan terapi konservatif (Prawirohardjo, 2007).

Beberapa peneliti menemukan hubungan antara obesitas dan menarche dini dengan peningkatan insiden mioma uteri. Wanita yang mempunyai Indeks Massa Tubuh (IMT) diatas normal, dan menarche dini ( $<12$ Tahun) berkemungkinan lebih sering menderita mioma uteri, dimungkinkan berhubungan dengan konveksi hormon androgen menjadi estrogen oleh enzim aromatase dijaringan lemak. Hasilnya terjadinya peningkatan jumlah estrogen tubuh, dimana hal ini dapat menerangkan hubungannya dengan peningkatan prevalensi dan pertumbuhan mioma uteri (Wijanjosastro, 2009).

Wanita yang sering melahirkan, sedikit kemungkinannya untuk perkembangan mioma ini dibandingkan dengan wanita yang tak pernah hamil atau hanya satu kali hamil. Statistik menunjukkan $60 \%$ mioma uteri berkembang pada wanita yang tidak pernah hamil atau hanya hamil satu kali. Prevalensi meningkat apabila ditemukan riwayat keluarga, ras, kegemukan dan nullipara (Kurniasari, 2010).

Diagnosis mioma uteri sering dicurigai bila bentuk uterus yang tidak teratur membesar teraba pada pemeriksaan panggul. Pemeriksaan Ultrasonografi (USG) adalah standar noninvasif utama yang digunakan untuk mengkonfirmasi diagnosis. USG bertujuan untuk mendeteksi karakteristik mioma uteri sehingga dapat dilakukan penanganan (Manuaba, 2009).

Upaya pemerintah dalam mewujudkan derajat kesehatan yang optimal selain untuk menurukan morbilitas ibu juga menurunkan morbiditas pada wanita, salah satunya dengan adanyan kebijakan pemerintah tentang kesehatan reproduksi melalui program Paket Kesehatan Reproduksi Esensial (PKRE) dan Paket Kesehatan Reproduksi Komprehensif (PKRK) bagi seluruh lapisan masyarakat Indonesia agar mencapai kesehatan reproduksi yang berkualitas (Depkes RI,2005). 
Studi prevalensi yang dilakukan di delapan Negara pada tahun 2009 melaporkan kejadian mioma uteri sebanyak 4,5\% pada wanita Inggris, 4,6\% Prancis, 5,5\% Kanada, 6,9\% Amerika Serikat, 7\% Brazil, 8\% Jerman, 9\% Korea, dan 9,8\% di Italia. Prevalensi mioma uteri mengalami peningkatan pada usia 40 tahun ke atas. Rata-rata mioma uteri didiagnosis pada rentang usia 33,5 hingga 36,1 tahun (Pasinggi, 2015).

Resiko mioma uteri meningkat seiring dengan peningkatan umur. Penelitian di Italia (2004) melaporkan 70 kasus mioma uteri dari 341 wanita pada usia 30-60 tahun dengan prevalensi 21,4\%. Di India (2006) terdapat 150 kasus mioma uteri, 77 kasus (51\%) terjadi pada wanita usia 40-49 tahun dan 45 kasus (30\%) terjadi pada wanita umur lebih dari 50 tahun (Pratiwi, 2012).

Berdasarkan otopsi, Novak menemukan 27\% wanita berumur 25 tahun mempunyai sarang mioma. Mioma uteri belum pernah (dilaporkan) terjadi sebelum menarche, setelah menopause hanya kira-kira 10\% mioma yang masih bertumbuh. Prevalensi terjadinya mioma uteri meningkat apabila ditemukan riwayat keluarga. Di Indonesia jumlah kejadian penyakit ini menempati urutan ke dua setelah kanker serviks. Mioma uteri ditemukan 2,39-11,7\% pada semua penderita ginekologi yang dirawat (Prawirohadjo, 2007).

Morbiditas yang ditimbulkan oleh mioma uteri cukup tinggi karena dapat menyebabkan nyeri perut dan perdarahan abnormal, serta diperkirakan dapat menyebabkan kesuburan rendah. Jika terjadi perdarahan abnormal yang berlebihan dapat menyebabkan anemia, penekanan pada kandung kemih yang menyebabkan sering berkemih dan urgensi, potensial untuk terjadinya sistitis dan penekanan pada rektum (Prawirohardjo, 2011).

Etiologi pasti belum diketahui, tetapi terdapat korelasi antara pertumbuhan tumor dengan peningkatan reseptor estrogen-progesteron pada jaringan mioma uteri, serta adanya faktor predisposisi yang bersifat herediter dan faktor hormon pertumbuhan dan Human Placental Lactogen. Para ilmuwan telah mengidentifikasi kromosom yang membawa 145 gen yang diperkirakan berpengaruh pada pertumbuhan fibroid. Beberapa ahli mengatakan bahwa mioma uteri diwariskan dari gen sisi paternal (Manuaba, 2010).

RSUD dr. Zainoel Abidin merupakan rumah sakit rujukan tipe-A di provinsi Aceh dan sekitarnya. Sebagai rumah sakit pemerintah sekaligus rumah sakit pendidikan, melayani persoalan-persoalan kesehatan dari segala aspek lapisan masyarakat. Termasuk dalam memberi pelayanan terhadap masalah kesehatan reproduksi diantaranya leimioma uteri. Berdasarkan data yang diperoleh selama tiga tahun terakhir tercatat kasus rawat jalan mioma 
uteri pada tahun 2014 sebanyak 430 kasus, tahun 2015 sebanyak 410 kasus, mioma uteri mengalami peningkatan pada tahun 2016 yaitu sebanyak 546 kasus dan tahun 2018 sebanyak 162 (Maret-Juli) kasus. mioma uteri merupakan masalah gynekologi kedua tertinggi setelah neoplasma ganas ovarium (RSUDZA, 2015).

Berdasarkan pada kenyataan di atas, maka hal ini mendorong peneliti untuk mengetahui lebih jauh mengenai Hubungan Faktor Risiko dengan Kejadian Leimioma Uteri di RSUD dr. Zainoel Abidin Banda Aceh Tahun 2018.

Untuk mengetahui Hubungan Faktor Risiko dengan Kejadian Leimioma Uteri di RSUD dr. Zainoel Abidin Banda Aceh Tahun 2018.

Penelitian ini diharapkan dapat menjadi pengalaman dan menambah wawasan bagi peneliti dan pembaca tentang Faktor Risiko Kejadian Leimioma Uteri Di RSUD dr. Zainoel Abidin Banda Aceh.

\section{METODE PENELITIAN}

Desain penelitian merupakan bagian penelitian berisi uraian-uraian tentang gambaran alur yang menggambarkan pola pikir penelitian dalam melakukan penelitian yang lazim disebut paradigma penelitin. Jenis penelitian yang digunakan adalah penelitian observasi analitik dengan pendekatan case-control.

Lokasi Penelitian ini dilakukan di RSUD dr. Zainoel Abidin Banda Aceh. Penelitian dimulai dari bulan maret-Juli 2018.

Populasi pada penelitian ini adalah semua wanita yang menderita mioma uteri di RSUD dr. Zainoel Abidin Banda Aceh periode Maret-Juli 2018. Penarikan sampel penelitian dilakukan dengan rumus kasus dan kontrol berpasangan yaitu 95\% confidence interval dan statistic power $80 \%$, besar sampel dalam penelitian ini di hitung dengan menggunakan rumus: Rumus Case-Control Berpasangan :

$n=\left[\frac{\mathrm{Z}_{\mathrm{q} / 2}+\mathrm{Z}_{\beta} \sqrt{\mathrm{PQ}}}{\left(\mathrm{P}-\frac{1}{2}\right)}\right]^{2} \quad \mathrm{P}=\frac{\mathrm{OR}}{(1+\mathrm{OR})}$

\section{Keterangan :}

n : Besar Sampel

P : Perkiraan Proporsi Paparan pada Kontrol

$\mathrm{R}$ : Odds Ratio

$\mathrm{Z}_{\alpha} \quad$ : Tingkat Kemaknaan 95\% $(1,96)$ 


\section{$\mathrm{Z}_{\beta} \quad$ : Power $80 \%(0,842)$}

Populasi dalam penelitian adalah semua Ibu yang memiliki Balita yaitu sebanyak 100 orang di Posyandu Desa Padang Kleng Kecamatan Teunom Kabupaten Aceh Jaya. Teknik Pengambilan sampel dalam penelitian ini dengan menggunakan total population yaitu dimana seluruh populasi dijadikan sebagai sampel yaitu sebanyak 100 ibu balita.

Jenis data yang di gunakan Data primer, data sekunder dan data tersier. Metode pengelohan data collecting, checking, coding, entering dan processing. Analisis data yang digunakan adalah analisis univariat dan analisis bivariat dengan uji chi-square.

\section{HASIL DAN PEMBAHASAN}

Berdasarkan tabel 1 dapat dilihat tabulasi silang variabel umur dengan kejadian mioma menunjukkan bahwa dari 106 responden yang berumur $\geq 35$ tahun yang mengalami mioma uteri sebanyak 64 responden $(42,1 \%)$ dan tidak mengalami mioma uteri sebanyak 42 responden $(27,6 \%)$, dari 46 yang berumur <35 tahun, sebanyak 12 responden $(7,9 \%)$ yang mengalami mioma uteri dan tidak mengalami mioma uteri sebanyak 34 responden $(22,4 \%)$.

Berdasarkan hasil analisis Chi-Square yang terdapat pada Tabel 4.7. diperoleh nilai $P$ value $=0,000$ (nilai $\alpha<0,05$ ) yang berarti Ho ditolak dan Ha diterima maka dapat disimpulkan bahwa ada hubungan umur dengan kejadian mioma uteri. Berdasarkan analisis OR diperoleh nilai Lower-Upper Limit (LL-UL) sebesar 4,317 (95\% CI = 2,010-9,274), menunjukkan bahwa responden yang berumur $\geq 35$ tahun 4 kali lebih beresiko mengalami mioma uteri.

Tabulasi silang variabel paritas dengan kejadian mioma menunjukkan bahwa dari 71 responden nullipara yang mengalami mioma uteri sebanyak 45 responden $(29,6 \%)$ dan tidak mengalami mioma uteri 26 responden $(17,7 \%)$, dari 81 responden yang memiliki paritas $\geq 1$ orang, sebanyak 31 orang $(20,4 \%)$ yang mengalami mioma uteri dan yang tidak mengalami mioma uteri sebanyak 50 responden $(32,9 \%)$.

Berdasarkan hasil analisis Chi-Square yang terdapat pada Tabel 4.8. diperoleh nilai $P$ value 0,003 (nilai $\alpha<0,05$ ), yang berarti Ho ditolak dan Ha diterima maka dapat disimpulkan bahwa ada hubungan paritas dengan kejadian mioma uteri. Berdasarkan analisis OR diperoleh nilai LL-UL sebesar 2,792 (95\% CI = 1,445-5,394), menunjukkan bahwa responden nullipara 2,8 kali lebih berisiko mengalami mioma uteri.

Tabulasi silang variabel Usia Menarche dengan kejadian mioma uteri menunjukkan bahwa dari 90 responden dengan usia Menarche $<12$ tahun, mengalami mioma uteri sebanyak 
55 responden $(36,2 \%)$ dan yang tidak mengalami mioma uteri sebanyak 35 responden $(23 \%)$ dari 62 responden yang usia Menarche $\geq 12$ tahun, sebanyak 21 responden $(13,8 \%)$ yang mengalami mioma uteri dan yang tidak mengalami mioma uteri 41 responden (27\%).

Berdasarkan hasil analisis Chi-Square yang terdapat pada Tabel 4.9. diperoleh nilai $P$ value 0,002 (nilai $\alpha<0,05$ ), yang berarti Ho ditolak dan Ha diterima maka dapat disimpulkan bahwa ada hubungan usia Menarche dengan kejadian mioma uteri. Berdasarkan analisis OR diperoleh nilai LL-UL sebesar 3,068 (95\% CI = 1,445-5,394), menunjukkan bahwa responden dengan usia Menarche <12 tahun 3 kali lebih beresiko mengalami mioma uteri.

Tabulasi silang variabel riwayat keluarga dengan kejadian mioma uteri menunjukkan bahwa dari 101 responden yang ada riwayat keluarga mengalami mioma uteri sebanyak 60 responden $(39,5 \%)$ dan yang tidak mengalami mioma uteri 41 responden (27\%) dari 51 responden yang tidak memiliki riwayat keluarga , sebanyak 16 responden (10,5\%) yang mengalami mioma uteri dan yang tidak memiliki riwayat keluarga sebanyak 35 responden $(23 \%)$.

Berdasarkan hasil analisis Chi-Square yang terdapat pada Tabel 4.9. diperoleh nilai $P$ value 0,002 (nilai $\alpha<0,05$ ), yang berarti Ho ditolak dan Ha diterima maka dapat disimpulkan bahwa ada hubungan riwayat keluarga dengan kejadian mioma uteri.

Berdasarkan analisis OR diperoleh nilai LL-UL sebesar 3,201 (95\% CI = 1,570-6,527), menunjukkan bahwa responden yang memiliki riwayat 3 kali lebih berisiko mengalami mioma uteri.

Tabel 1. Tabulasi Silang Hubungan Faktor Risiko dengan Kejadian Leimioma Uteri di RSUD dr. Zainoel Abidin Banda Aceh Tahun 2018

\begin{tabular}{|c|c|c|c|c|c|c|c|c|}
\hline \multirow{3}{*}{ Analisis Bivariat } & \multicolumn{4}{|c|}{ Kejadian Mioma Uteri } & \multirow{3}{*}{$\mathbf{N}$} & \multirow{3}{*}{ p-Value } & \multirow{3}{*}{ OR } & \multirow{3}{*}{ (CI95\%) } \\
\hline & \multicolumn{2}{|c|}{ Kasus } & \multicolumn{2}{|c|}{ Kontrol } & & & & \\
\hline & $\mathbf{n}$ & $\%$ & $\mathbf{n}$ & $\%$ & & & & \\
\hline \multicolumn{9}{|l|}{ Umur } \\
\hline$\geq 35$ & 64 & 42.1 & 42 & 27.6 & 106 & \multirow{2}{*}{0,000} & \multirow{2}{*}{4.317} & \multirow{2}{*}{$(2.010-9.274)$} \\
\hline$<35$ & 12 & 7.9 & 34 & 22.4 & 46 & & & \\
\hline \multicolumn{9}{|l|}{ Paritas } \\
\hline Nullipra & 45 & 29.6 & 26 & 17.1 & 71 & \multirow{2}{*}{0,003} & \multirow{2}{*}{2.792} & \multirow{2}{*}{$(1.445-5.394)$} \\
\hline$\geq 1$ & 31 & 20.4 & 50 & 32.9 & 81 & & & \\
\hline \multicolumn{9}{|l|}{ Usia Menarche } \\
\hline$<12$ & 55 & 36.2 & 35 & 23 & 90 & \multirow{2}{*}{0,002} & \multirow{2}{*}{3.068} & \multirow{2}{*}{$(1.561-6.028)$} \\
\hline$\geq 12$ & 21 & 13.8 & 41 & 27 & 62 & & & \\
\hline \multirow{2}{*}{\multicolumn{9}{|c|}{ Riwayat Keluarga }} \\
\hline Ada & 60 & 39.5 & & & & & & \multirow{2}{*}{$(1.570-6.527)$} \\
\hline Tidak Ada & 16 & 10.5 & 35 & 23 & 51 & 0.002 & 3.201 & \\
\hline
\end{tabular}




\section{Hubungan Umur dengan Kejadian Mioma Uteri}

Berdasarkan penelitian retrospektif pada status rekam medik pasien di bagian Kebidanan dan Penyakit Kandungan RSUDZA Banda Aceh Periode Maret-Juli 2018 didapatkan 76 sampel yang merupakan penderita mioma uteri berdasarkan hasil pemeriksaan Histopatologi bagian Patologi Anatomi dan 76 sampel yang tidak mengalami mioma uteri di RSUDZA Banda Aceh.

Kejadian mioma uteri juga dipengaruhi oleh umur responden. Pada penelitian ini jumlah kasus mioma uteri terbanyak terdapat pada kelompok umur $\geq 35$ tahun yaitu sebesar 64 responden (42,1\%). Berdasarkan penelitian uji statistik dengan Chi-Square Test diperoleh hasil bahwa umur berpengaruh terhadap kejadian mioma uteri di RSUDZA Banda Aceh tahun 2018 dengan nilai $P$-value=0,000 (nilai $\alpha<0,05$ ); OR sebesar 4,317 LL-UL sebesar (95\% CI=(2,010-9,274) menunjukkan bahwa responden yang berumur $\geq 35$ tahun 4,431 kali berpeluang mengalami kejadian mioma uteri dibandingkan responden berumur <35 tahun. Hormon estrogen diperkirakan mempengaruhi pertumbuhan mioma uteri, membutuhkan waktu lama untuk menumbuhkan mioma uteri makn bertambahya umur maka estrogen akan memberi ransangan yang terus menerus setiap bulan dari hormon estrogen membuat peluang yang besar untuk pertumbuhan mioma uteri dimana menjadi berlapis seperti bawang dari waktu kewaktu (Bobak, 2012).

Hasil ini sejalan dengan penelitian Lilyani di RSUD Tugurejo Semarang menunjukkan ada hubungan yang signifikan antara umur dengan kejadian mioma uteri dengan nilai $p=0,007$ serta diperkuat oleh Wikjosastro yang mengatakan bahwa kasus mioma uteri tertinggi pada usia 35-49 Tahun. Hal ini disebabkan karena pertumbuhan dan perkembangan mioma uteri dipengaruhi oleh stimulasi hormon estrogen yang disekresikan oleh ovarium. Pada umumnya mioma uteri jarang timbul sebelum Menarche dan sesudah menopause banyak mioma uteri menjadi lisut, hanya $10 \%$ saja yang masih tumbuh lebih lanjut. Hal ini disebabkan karena pada usia sebelum Menarche kadar estrogen rendah, dan meningkat pada usia reproduksi serta akan turun pada usia menopause. Hormon estrogen disekresi oleh ovarium mulai saat pubertas berangsurangsur meningkat dan akan mengalami penurunan bahkan tidak berproduksi lagi setelah usia menopause (Kurniasari, 2009). 


\section{Pengaruh Paritas dengan Kejadian Mioma Uteri}

Kejadian mioma uteri juga dipengaruhi oleh jumlah paritas. Pada penelitian ini jumlah kasus mioma uteri terbanyak terdapat pada wanita dengan kelompok nullipara yaitu sebesar 45 responden (59,2\%). Berdasarkan Hasil uji statistik dengan Chi-Square Test diperoleh hasil bahwa paritas berpengaruh terhadap kejadian mioma uteri di RSUDZA Banda Aceh tahun 2018 dengan nilai $P$-value=0,003 (nilai $\alpha<0,05$ ) dan nilai OR sebesar 2,792 LL-UL sebesar $(95 \%$ CI=(1.445-5,394) menunjukkan bahwa responden nullipara 2,792 kali berpeluang mengalami kejadian mioma uteri dibandingkan responden parita $\geq 1$ orang.

Penelitian ini sesuai dengan pendapat Parker yang menyatakan bahwa peningkatan jumlah paritas akan menurunkan risiko terjadinya mioma uteri. Mioma uteri memiliki karakteristik yang serupa dengan miometrium normal selama kehamilan, termasuk peningkatan produksi matriks ekstra seluler dan peningkatan ekspresi reseptor hormon steroid dan peptida. Miometrium selama postpartum kembali pada keadaan normal baik dalam ukuran dan aliran darah melalui proses apoptosis dan dediferensiasi. Proses remodeling ini berperan dalam involusi mioma yang responsibel. Teori lain menyatakan bahwa suplai aliran darah ke mioma akan berkurang selama involusi uterus akibat nutrisi yang ikut berkurang (ASRM, 2007).

Paritas merupakan banyaknya kelahiran hidup atau jumlah anak yang dimiliki oleh wanita, klasifikasi paritas : nullipara (belum pernah hamil sampai dengan cukup bulan), primipara (sudah pernah melahirkan seorang anak), multipara (sudah melahirkan anak lebih dari satu kali), dan grandemultipara (sudah pernah melahirkan anak lebih dari lima anak) (Sibagariang, 2010).

Pada wanita kelompok nullipara, kejadian mioma uteri lebih sering ditemui salah satunya diduga karena sekresi estrogen wanita hamil sifatnya sangat berbeda dari sekresi oleh ovarium pada wanita yang tidak hamil yaitu hampir seluruhnya estriol, suatu estrogen yang relatif lemah dari pada estradiol yang disekresikan ovarium. Hal ini berbeda dengan wanita yang tidak pernah hamil atau melahirkan, estrogen yang ada di tubuhnya adalah murni estrogen yang dihasilkan oleh ovarium semuanya digunakan untuk proliferasi jaringan uterus (Kurniasari, 2009).

Hal ini sejalan dengan yang dikemukakan oleh Wiknjosastro bahwa mioma uteri lebih sering dijumpai pada wanita nullipara atau kurang subur hal ini berkaitan juga 
dengan keadaan hormonal. Beberapa penelitian menemukan hubungan saling berbalik antara paritas dan munculnya myoma uteri. Hal ini disebabkan besarnya jumlah reseptor estrogen yang berkurang di lapisan miometrium setelah kehamilan (Wiknjosastro, 2009). Mioma uteri berdampak pada ketidak suburan pada wanita, jika mioma uteri tumbuh pada kanula tuba dekat insersio maka akan mengganggu gerak spermatozoa, dan menutup tuba fallopi, Mioma uteri sebagai penyebab infertilitas hanya dijumpai pada $2-10 \%$ kasus. Infertilitas terjadi sebagai akibat obstruksi mekanis tuba falopi (Manuaba, 2009).

\section{Pengaruh Usia Menarche dengan Kejadian Mioma Uteri}

Kejadian mioma uteri juga dipengaruhi oleh usia Menarche. Pada penelitian ini jumlah kasus mioma uteri terbanyak terdapat pada wanita dengan kelompok usia Menarche $<12$ tahun yaitu sebesar 55 responden $(72,4 \%)$.

Berdasarkan Hasil uji statistik dengan Chi-Square Test diperoleh hasil bahwa usia Menarche berpengaruh terhadap kejadian mioma uteri di RSUDZA Banda Aceh tahun 2018 dengan nilai $P$-value=0,002 (nilai $\alpha<0,05$ ) dan nilai OR sebesar 3,068 LL-UL sebesar $(95 \% \mathrm{CI}=(1,561-6,028)$ menunjukkan bahwa usia Menarche $<12$ tahun 3,068 kali berpeluang mengalami kejadian mioma uteri dibandingkan usia Menarche $\geq 12$ tahun.

Menarche adalah priode menstruasi pertama kali. Menstruasi atau haid merupakan peluruhan dinding rahim yang terdiri dari darah jaringan tubuh. Kejadian iniberlangsung setiap bulan pada perempuan. Usia normal Menarche adalah 12 tahun, sebagian perempuan mengalami haid lebih awal yaitu >12 tahun dan lebih lambat yaitu 18 tahun (Sibagariang, 2010).

Menarche dini berkemungkinan lebih sering menderita mioma uteri dimungkinkan berhubungan dengan konveksi hormon androgen menjadi estrogen oleh enzim aromatase dijaringan lemak. Hasilnya terjadinya peningkatan jumlah estrogen tubuh, dimana hal ini dapat menerangkan hubungannya dengan peningkatan prevalensi dan pertumbuhan mioma uteri(4). Wanita dengan usia Menarche dini akan terpapar dengan hormon estrogen dalam periode yang lebih lama/panjang, sehingga wanita dengan kondisi ini memiliki resio lebih tinggi terpapar mioma uteri.

Hasil penelitian ini sejalan dengan yang dikemukakan Parker bahwa usia Menarche beresiko terhadap kejadian mioma uteri (Winkjosastro, 2009). Sejalan juga dengan 
penelitian Lilyani bahwa terdapat hubungan bermakna antara umur Menarche dengan kejadian mioma uteri dengan nilai $(\mathrm{p}=0,007)$ (Lilyani, 2012).

\section{Pengaruh Riwayat Keluarga dengan Kejadian Mioma Uteri}

Kejadian mioma uteri juga dipengaruhi oleh adannya riwayat keluarga. Pada penelitian ini jumlah kasus mioma uteri terbanyak terdapat pada wanita dengan kelompok ada riwayat yaitu sebesar 60 orang (78,9\%). Berdasarkan hasil uji statistik dengan Chi-Square Test diperoleh hasil bahwa riwayat keluarga berpengaruh terhadap kejadian mioma uteri di RSUDZA Banda Aceh tahun 2018 dengan nilai $P=0,002$ (nilai $\alpha<0,05)$ dan nilai OR sebesar 3.201 LL-UL sebesar (95\% CI=(1,570-6,5327) menunjukkan bahwa riwayat keluarga 3,201 kali berpeluang mengalami kejadian mioma uteri dibandingkan responden yang tidak memiliki riwayat keluarga.

Wanita dengan garis keturunan tingkat pertama dengan penderita mioma uteri mempunyai 2,5 kali kemungkinan untuk menderita mioma dibandingkan dengan wanita tanpa garis keturunan penderita mioma uteri hal ini diakarenakan adanya GEN turunan dari keluarga (Winkjosastro, 2009). Para ilmuwan telah mengidentifikasi kromosom yang membawa 145 gen yang diperkirakan berpengaruh pada pertumbuhan fibroid. Beberapa ahli mengatakan bahwa mioma uteri diwariskan dari gen sisi paternal (Anwar, 2011).

\section{KESIMPULAN}

Kesimpulan peneliti ini ada hubungan antara faktor risiko umur ibu, paritas, usia menarche dan riwayat keluarga denagan kejadian mioma uteri di di RSUD dr. Zainoel Abidin Banda Aceh Tahun 2018.

\section{SARAN}

Diharapkan kepada masyarakat Banda Aceh lebih memperhatikan faktor risiko agar dapat mengurangi angka kejadian morbiditas dan mortalitas dengan mengikuti penyuluhan kesehatan.

\section{DAFTAR PUSTAKA}

Anwar, S. M, Baziad A, Prabowo P. Ilmu Kandungan. Edisi ke 3.Jakarta: PT Bina Pustaka Sarwono Prawirohardjo: 2011;

ASRM. Diagnosis of Uterine Myomas.Department of Obstetrics and gynecology UCLA 
School of Medicine. California : American Society for Reproductive Medicine 2007. Tersedia dari:

http://www.reproductivefacts.org/uploadedFiles/ASRM_Content/News_and_Publicati ons/Selected_Articles_from_Fertility_and_Sterility/myoma_etiology.pdf.

Bobak IM, dkk. Editor. Buku Ajar Keperawatan Maternitas. Edisi-4. Jakarta: EGC:2012. Hlm. 50-52.

Depkes RI. UU RI NO.23 TAHUN 2005 tentang Kesehatan. DepKes: 2005.

Kurniasari T. Karakteristik mioma uteri di RSVD Dr. Moewardi Surakarta Periode Januari 2009-Januari 2010 [Skripsi]. 2010 [di unduh 20 Oktober 2016]: Tersedia dari : http://eprints.uns.ac.id/35/1/170212311201010031.pdf.

Lilyani, D.I. Hubungan faktor resiko dan kejadian mioma uteri di RSUD

Manuaba,I.B.G. Memahami Kesehatan Reroduksi Wanita. Edisi 4. Jakarta: Penerbit EGC; 2009.

: Penuntun Kuliah Gynekologi. Jakarta: CV. Trans Info Media: 2010.

: Editor Buku Ajar Gynekologi. Jakarta:EGC: 2010. Hlm 318-329.

Muhammad, I. Pemanfaatan SPSS Dalam Penelitian Bidang Kesehatan. Bandung: Cita Pustaka Media Perintis: 2012.

: Karya Tulis BIdang Kesehatan. Bandung: Cita Pustaka Media Perintis: 2012.

Najmah. Epidemiologi. Edisi ke 2. Jakarta: PT Rajagrafindo Persadi: 2015. Hlm 44.

Notoatmodjo S. Metodologi penelitian kesehatan. Jakarta: Rineka Cipta: 2010. Hlm. 41-43.

Pasinggi, S. Prevalensi Mioma Uteri Berdasarkan Umur di RSUP Prof. DR.R.D. Kandou Manado. [Journal]. 2015 [di unduh 11 November 2016]: Tersedia dari : http://download.portalgaruda.org/article.php?article=291778\&val=1001\& title=PREVA LENSI\%20MIOMA\%20UTERI\%20BERDASARKAN\%20UMUR\%20DI\%20RSUP\% 20PROF.\%20DR.\%20R.\%20D.\%20KANDOU\%20MANADO.

Pratiwi, L. Hubungan usia reproduksi dengan kejadian mioma uteri di RSVP Prof. Dr. R. D. Kandou Manado [Skripsi]. 2012 [di unduh 12 November 2016]: Tersedia dari : http://download.portalgaruda.orang/article.php?article=14973\&val= 1001 .

Prawirohardjo, S. Ilmu Kebidanan. Edisi ke 4.Jakarta: PT Bina Pustaka Sarwono Prawirohardjo; 2011.

: Ilmu kebidanan. Edisi ke-3. Cetakan ke-9. Jakarta: Yayasan Bina Pustaka Sarwono Prawirohardjo; 2007.

Proverawati. Obesitas dan Ganguan Prilaku Makan Pada Remaja. Yokyakarta:Nuha Medika.2010.

Rumah Sakit Umum Daerah dr. Zainoel Abidin (RSUDZA). Data keadaan mortalitas pasien rawat inap rumah sakit: 2013-2015.

Sastroasmoro S, Ismael S. Dasar-dasar metodologi penelitian klinis. Edisi ke-4. Cetakan ke-2. Jakarta: Sagung Seto: 2012. Hlm. 99, 148, 369-370. 
Sibagariang EE, dkk. Kesehatan Reproduksi Wanita. Jakarta: Trans Info media: 2010. Hlm. 32.

Susila, Suyanto. Metode PenelitianRetrospektif Case-Control.Klaten: Bossscript: 2015. Hlm $3-5$.

Wiknjosastro, D H. Ilmu Kandungan. Jakarta: Yayasan Bina Pustaka Sarwono Prawirohardjo; 2009.

Yhantiaritra. Kategori Umur Menurut DEPKES RI 2009.2015 [diunduh 12 Februari 2018]: Tersedia dari : https:// yhantiaritra.wodpress.com/2015/06/03/kategori-umur-menurutdepkes/. 